УДК 94(571. 1/.5) «XVIII-XX»

DOI: $10.17223 / 19988613 / 47 / 4$

\title{
С.В. Смокотин
}

\section{ПРАВОСЛАВНАЯ ЦЕРКОВЬ И КРЕСТЬЯНСТВО В ТОМСКОЙ ГУБЕРНИИ В ХІХ - НАЧАЛЕ ХХ в.}

\begin{abstract}
В XIX - начале XX в. крестьянство составляло большую часть населения Российской империи. В Сибири, вследствие удаленности от центра страны, слабого контроля со стороны светских и церковных властей, местное население сравнительно равнодушно относилось к православной церкви. Вместе с тем сельское население в XIX - начале XX в. продолжало сохранять традиционные обычаи и культуру. Однако религиозность крестьян отличалась от канонического понимания христианства, была смешана с суевериями и магизмом. Все эти недостатки постепенно преодолевались насаждением цивилизации и культуры среди народа. Православная церковь также занималась просветительской и благотворительной деятельностью - открытием церковно-приходских школ, приходских попечительств, организацией духовнонравственных чтений для народа. В работе использованы материалы, опубликованные в церковной периодике и справочных изданиях XIX - начала XX в.

Ключевые слова: крестьянство; православие; церковь; раскол; суеверия.
\end{abstract}

Статья посвящена изучению проблемы взаимоотношения Русской православной церкви и крестьянства Томской губернии, которое составляло подавляющую часть населения губернии в конце XIX начале ХХ в. [1. С. 185]. Хотя с начала заселения Западной Сибири русскими к тому времени прошло около трех веков, степень религиозности крестьян была слабой. Известный историк и этнограф князь Н.А. Костров в составленной им в 1868 г. записке «О расколе в Томской губернии», писал: «Из указаний летописцев, из дел царского времени, наконец, из народных сказаний, нам известно, что первый колонист Сибири был совершенно индифферентен к религии, постов не соблюдал, в церковь ходил редко, пил когда только можно было пить, играл в зернь, курил табак, на брачные отношения смотрел со своей особенной точки зрения, имея иногда в различных пунктах края три, пять и более жен, из которых ни с одной не был венчан по церковным постановлениям» [2. С. 499-500]. Одной из причин бедности монастырей Сибири в XVIII в. был независимый, строптивый дух местных монастырских крестьян, соседствовавших не с крепостными, а с государственными крестьянами, и стремившихся обрести такие же права, как и последние [3. С. 182].

О равнодушии сибиряков к церкви свидетельствовали Томские епископы, жаловавшиеся на свою паству, нередко избегавшую богослужений и церковных обрядов. В ее среде можно было встретить таких, кто не исповедался и не причащался в течение всей своей жизни, обращаясь к священнику только в самых крайних случаях - тяжелых жизненных ситуациях или перед смертью. В некоторых приходах случалось, что церкви были пусты даже в великие праздники [4. С. 42]. В отчете управы благочиния за 1891 г. сообщалось: «Прихожане православные не чуждаются духовенства, но и не так близко стоят к нему, как бы следовало. Священники при всяком удобном случае стараются сказать своим прихожанам что-нибудь назидательное. Обыкновенно в таких случаях прихожане дают обещание исправиться, но эти обещания скоро забываются и остаются без исполнения... Многие редко бывают у исповеди и причастия. Некоторые православные не приглашают священников к отпетию умерших, а хоронят сами, и просят об отпетии после - или в церкви, или при случае на могиле» [5. С. 5]. В том же году в указанном отчете отмечалось, что из 29980 лиц мужского и 30282 лиц женского пола на исповеди и причастии были 8636 мужчин и 10159 женщин (менее 1/3 всех прихожан). Многие крестьяне исповедались через 23 года и более. Большая часть не посещала церковь, поскольку не была «приучена родителями с детства», а многие ограничивались посещением храмов лишь в великие праздники и во время великого поста. Жители деревень, в отличие от сельского населения, в храмах своего прихода бывали еще реже. Немногие из них - в великие праздники или приезжали «для крещения или причащения младенцев, или чтобы отслужить по особому обету молебен» [Там же. С. 7]. Публицист И. Новиков, автор обзорной статьи «Томская епархия в 1900 г.», приводит слова, услышанные им от одного из священников о том, что сибиряк посещает церковь скорее «для очищения совести, чтобы не прослыть безбожником, а иногда просто только для того, чтобы показать на народе свою обнову $<\ldots>$. [В церковь] ходят мало и почти исключительно только те, которые живут при церкви» [6. C. 13-15].

Русский православный священник, как правило, кормился от прихода, поэтому в Томской губернии такая ситуация оборачивалась для части духовенства немалыми материальными и бытовыми трудностями. Епископ Макарий (Невский) во время своих объез- 
дов епархии пытался, иногда небезуспешно, взывать к совести прихожан и принимать меры к их исправлению. В январе 1901 г. в селе Константиновском он провел беседу о «почитании священного сана», напомнив, что константиновцы в прошлом не заботились о материальных нуждах своих пастырей. В наказание жители села были временно оставлены без священника, после чего изменили свое поведение. Были случаи, когда крестьяне не желали строить и ремонтировать причтовые дома, заботиться о церковном благоустройстве, отказывались платить священнику и причту при традиционном обходе теми домов в праздники. В деревне Килиной крестьяне выстроили школу, но не построили обещанную ими часовню. Жители села Конининского собирались жертвовать на благотворительные цели по одному пуду с десятины собранного ими хлеба, но не исполнили обещанного [7. С. 17-18].

В конце XIX - начале XX в. паства православной церкви значительно увеличилась за счет переселенцев из центральных и южных губерний Российской империи с их культурными, бытовыми отличиями от старожилов. В церковной периодике отмечалось, что в сравнении с местным населением они не были индифферентны к религии, охотно посещали церковные службы, регулярно исповедались и причащались. «На редкое благое начинание, - утверждал один священник, - не откликнется прихожанинпереселенец и, не жалея, жертвует, чем может. Детей своих старается выучить грамоте и радуется, когда видит их читающими или поющими в церкви». Переселенцы достаточно хорошо знали символ веры, заповеди, начальные молитвы. В этом они также отличались от сибиряков, среди которых имели хождение самодельные молитвы и апокрифы [6. С. 13-14].

Еще одной причиной того, что старожилы избегали церкви, могла быть явная или скрытая приверженность старообрядчеству. Насколько велик был удельный вес старообрядцев среди всего остального населения Томской губернии? Согласно «Статистическому очерку Томской губернии», изданному в 1892 г., в 1885 г. в ней проживали 27673 «раскольника», или 2,32\% населения, при 107 1853, или $89,56 \%$, православных и единоверцев. Эти цифры могут быть не совсем точны. В единоверцы часто записывались старообрядцы, стремившиеся таким образом избежать преследований со стороны государственной власти и Синодальной церкви. Кроме того, официальная статистика имела склонность намеренно занижать число старообрядцев. «Памятная книжка Томской губернии на 1912 г.» дает следующие цифры: православные - 3552878 (91,57\%), «раскольники» - 147632 (3,81\%), единоверцы 41164 (1,07\%). Бо́льшая часть старообрядцев и единоверцев проживала в сельской местности [1. C. 184].
Таким образом, удельный вес старообрядцев и единоверцев в Томской губернии, возможно, был около 5\% от общей численности населения. Например, в благочинии № 26 в 1891 г. у исповеди и причастия «по нерадению» не присутствовали 28218 человек, и лишь 3180 человек открыто объявили о своей принадлежности к «расколу». В 1901 г. на первом месте по количеству старообрядческого населения был Барнаульский уезд (35 тыс.). Затем следовали Бийский уезд (22 тыс.), Змеиногорский (17 тыс.), Каинский (6 тыс.), Кузнецкий (5 тыс.), Мариинский и Томский (по 4 тыс.). Представлено старообрядчество было по большей части тремя беспоповскими согласиями поморцами, нетовцами, стариковцами, а также поповцами, принадлежавшими к Белокриницкой иерархии («австрийцы») [8. С. 1].

Относительная немногочисленность старообрядцев и неравномерность их расселения в губернии были причинами того, что влияние, оказываемое ими на православное население, во многом зависело от удельного веса в той или иной местности. Чем больше старообрядцев жило в селе, тем это влияние было заметнее. «Раскольников в деревне Тарасовой большая половина жителей ее, а уклоняющихся от исполнения святых таин - почти весь приход», - писал в 1891 г. миссионер священник Михаил Кандауров [9. С. 11]. Отрицательное отношение к официальной церкви передавалось от старообрядцев к колеблющейся части православных. Один из миссионеров, священник Филарет Синьковский, рассказывал о своей беседе в селе Тоурак с крестьянином, ушедшим в раскол, затем вернувшимся обратно в православие. «Да мы, батюшка, не совсем раскольники, заявил крестьянин, - ну, да и православными шибко назвать нас нельзя. Мы от своего берега отстали, а к другому не пристали» [10. С. 127-128].

В отчете Алтайской духовной миссии за 1880 г. сообщалось, что после совершения начальником миссии водосвятия в деревне Коксе сельский староста заставил одного из «полуправославных» сельчан «убрать из деревни вон, куда хочет» свой большой медный крест, хотя и старинный, но «обмирщенный», поскольку использовался при совершении «никонианского» молебна. В деревне Нижнем Уймоне старообрядцы падали ниц при архиерейском благословении, поскольку «чрез этот маневр их благословение православного епископа пролетит над ними не коснувшись их» [11. С. 235].

Борьба с расколом занимала значительное место в деятельности епархиальных миссионеров и широко освещалась на страницах «Епархиальных ведомостей». В опубликованных миссионерских отчетах отмечается низкий уровень знаний и беспомощная полемика местных старообрядческих наставников, что кажется весьма правдоподобным («начетчики плохие»; «все наставники, кроме умения читать и писать никакой начитанности не имеют»). Один из 
авторов, в частности, писал, что многие прихожане любили читать трудно понимаемые ими пророческие книги Библии. За объяснением прочитанного они пытались обращаться к местным священникам и иным лицам, но те не были способны это сделать. Летом 1886 г., повествует автор, один из преподавателей семинарии, находясь в деревне, вел частые и долгие беседы о Писании с одним крестьянином, удивляясь «его начитанности и остроумным, хотя большей частью неправильным толкованиям трудных мест библейских» [12. С. 6].

Раскол и сочувствие ему среди части крестьянского населения создавали порой значительные трудности для приходского духовенства, как правило, обремененного многодетными семьями, материальное и бытовое благополучие которого зависело от прихожан. «В настоящее время положение сельского духовенства в Томской губернии, как и по всей Сибири вообще, - писал в 1868 г. князь Николай Костров, - достойно полного сожаления $<\ldots>$, так как на его обязанности преимущественно и лежит борьба с расколом. Теперь каждый сельский священник может считать себя материально обеспеченным только тогда в той мере, в какой он умел приобрести себе расположение прихода» [13. С. 531-532].

Сельское население Сибири, как и по всей России в целом, в XIX и даже в начале XX в. продолжало сохранять обычаи и культуру, свойственные традиционному обществу. Сознание крестьян было религиозным в большей степени, чем жителей городов, но эта религиозность, которую можно назвать «бытовым христианством», или «народной церковностью», отличалась от канонического, официального, строго церковного понимания христианства, была смешана с суевериями, магизмом, апокрифами. Суеверия, бытовавшие среди томских крестьян, описывал князь Н.А. Костров в очерке «Колдовство и порча между крестьянами Томской губернии». Ознакомившись со статьей Барсова «Очерки народного мировоззрения и быта», опубликованной в журнале «Древняя и Новая Россия» в 1876 г., в которой тот писал, что «Главными руководителями и решителями в семейных делах народа доныне служат ведуны и колдуны, знахари и колдуньи», Костров взялся рассмотреть состояние этого вопроса в приложении не к великороссийским областям, а к Томской губернии. В своем небольшом очерке он собрал некоторые архивные материалы, относящиеся к XVIII и к первой половине XIX в.

В 1815 г. крестьянская девка Прасковья Плотникова была поймана за тем, что сажала в бутылку живого змееныша. Она собиралась залить его квасом, настоять и отравить односельчанина по просьбе жены последнего. Крестьяне пытались наводить на недругов порчу, применяя различные способы: опускали в щи сушеную лягушку, держали в горшке лягушку со змеей. Лечили заговорами: заговаривали от болезней и от укуса змеи, использовали змеиную кожу с заговором от лихорадки. Готовили привороты и отвороты. Несколько крестьянских заговоров того времени приводится в вышеупомянутом очерке Н.А. Кострова. Лягушек использовали как средство против запоя («для этого нужно живую лягушку посадить в вино и поставить его на сутки в теплое место, а потом настой этот давать пить подверженному запою, однако же так, чтобы он не знал, что пьет»). Чтобы добиться к себе любви в семье, женщины изготовляли снадобье из месячных. Верили в то, что внутри испорченного человека может жить лягушка. Один крестьянин показывал на следствии, что жена его родила двух кротов [14. С. 11-16].

Наряду с невежеством и религиозной индифферентностью населения церковь постоянно обличала нравственные пороки; наиболее укоренившимися в народе были пьянство и сквернословие. Священник И. Б-нов, автор «Поучения к сельским прихожанам. О пагубных последствиях пьянства», в 1880 г. писал, что питейные заведения посещают люди разного возраста и пола, среди которых встречаются совсем молодые и неопытные, и даже девицы. Обходя как священник дома крестьян, он зашел в один из домов, увидев в нем хозяина, пьяного до бесчувствия. «Вокруг него и по нем ползают его дети, один другого меньше, и с воплем просят у него: “Тятя, дай хлеба!”». Так ничего и не дождавшись, дети отходят от полумертвого отца. Священник пишет, что матери у них нет [15. С. 205].

Привычку пьянствовать имели не только православные, но и часть крестьян, причислявших себя к старообрядцам. Встречается и утверждение, что переселенцы были более привержены к вину, чем старожилы, у которых «особенно безобразное пьянство бывает во время свадеб. Здесь пьянствуют не только взрослые мужчины, но и женщины, девицы и даже дети. Такой пьяный разгул редко кончается мирно, а по большей части дракой, дикой оргией и другими злокачественными явлениями». Поводом для всеобщего пьянства становились и поминки по усопшим. В сороковой день поминки нередко происходили на открытом воздухе, прямо возле питейного заведения родственники поминаемого угощали желающих вином и сластями.

В отличие от переселенцев, сибиряки поминали усопших, устраивая обед без вина, на который приглашались старики и старухи. «На этом обеде сначала все долго молятся, затем тихо и скромно обедают, опять помолятся и расходятся». Сибиряки и переселенцы строго соблюдали пост, «но соблюдение постов исключительно состоит в воздержании от скоромной пищи, упиваться же вином и предаваться другим порокам не стесняются и в пост». Праздники проводили в ничегонеделании, играх, гулянках с пьянством. Считалось, что в церковные праздники грех работать на себя, но можно работать на других, 
отправляясь на поденные работы. Причем особенно популярны среди крестьян были так называемые «помочи» - поденщина, за которую хозяева расплачивались не деньгами, а вином и угощением. Крестьяне часто сожительствовали с чужими женами и мужьями, особенно не раскаиваясь и рассматривая такое сожительство, как легкий, «птичий грех». Сибиряки сильно сквернословили, удивляя этим даже переселенцев. Миссионер священник Филарет Синьковский жаловался, что сквернословию у русского населения выучились крещеные и некрещеные алтайцы, «притом некоторые из некрещеных ничего не знают по-русски, кроме бранных слов» [10. С. 125].

Перепечатанная из «Киевских епархиальных ведомостей» в местной церковной газете статья «Хорошие методы для отвлечения народа от пьянства» призывала православное духовенство «приобрести репутацию наиболее трезвого сословия в целом народе и обществе». Для достижения этой благой цели ему рекомендовалось избегать совершения богослужений в нетрезвом виде и участвовать в попойках по случаю крестин, свадеб, поминок и т.д. [16. С. 498-499]. Отрицательно влияли на нравственный климат в губернии и ссыльные, несколько тысяч которых ежегодно выселяли в Сибирь. Они воровали, пьянствовали, совершали убийства [4. С. 43].

Справедливости ради необходимо признать, что картина сельской жизни в Томской губернии состояла не из одних только мрачных картин. Современники отмечали такие крестьянские черты, присущие в первую очередь сибирякам, как гостеприимство, странноприимство, подачу милостыни нуждающимся.

Были особенные примеры чистой жизни и высокой нравственности. В 1889 г. «Епархиальные ведомости» рассказали историю мещанина К.В. Орехова, проживавшего в селе Елбанском, который на свои собственные средства завел в селе школу, купил дом и мебель. Однако (дело происходило в 1870-х гг., и школа должна была относиться к гражданскому ведомству) не получил разрешения на открытие школы, поскольку не мог ее содержать в дальнейшем. В 1884 г. было разрешено открыть в селе церковноприходскую школу, и Орехов приобрел для нее новый дом, уже двухэтажный.

В июне 1885 г. Орехов умер, и попечителем школы стал его приемный сын, купец С.И. Виноградов, жертвовавший ежегодно по двадцать рублей на нужды школы и содержавший сторожа [17. С. 18-19].

На улучшение нравственного климата в селе и церковную активность прихожан могли оказывать благотворное влияние иные сложившиеся местные традиции. При Спасской церкви села Спасское Томского уезда находилась икона Спаса, которую ежегодно в конце мая приносили в Томск, а в деревне Ипатовой, находившейся в том же приходе, - почитаемая народом икона Николая Чудотворца. Благодаря этому, утверждали местные церковные власти, «религиозно-нравственное настроение прихожан вообще доброе, что редко можно встретить в пригородных приходах и селениях» [18. С. 17-18].

Все эти недостатки постепенно, с трудом, но преодолевались не только проповедями, молебнами и крестными ходами, но и насаждением цивилизации и культуры среди крестьянского народа. С «Великими реформами» по всей стране организуются земства, создается сеть сельских школ, появляются земские больницы. В дело просвещения вносила свое посильное участие и православная русская церковь. В конце XIX - начале XX в. открываются церковноприходские школы. По данным на 1899 г. в Томской губернии было 1028 таких школ: 1 церковноучительская, 3 второклассных, 3 двухклассных, 204 одноклассных и 815 школ грамоты. В 1901 г. числилась 921 церковноприходская школа. (Это школы, о которых в консисторию были представлены статистические сведения, так называемые школьные листки.)

По требованию церковного начальства при всех церквях епархии создавались библиотеки с книгами догматического, учительного, религиознофилософского содержания и церковными периодическими изданиями. Пользовались библиотеками как духовенство (для самообразования и подготовки к внебогослужебным собеседованиям), так и прихожане, которым также разрешалось брать книги на дом. Количество книг в них было разным - от 10 до 600 наименований. Наиболее богатые приходские библиотеки были при церквях села Моралиха, Колыванском заводе, сел Калманское и Павловское.

В епархии также создавались приходские попечительства, целью которых было оказание помощи бедным своего прихода. Помощь могла быть и финансовой, а могла состоять из пищи и одежды, обуви. Такие попечительства создавались вначале при городских, а затем и при сельских церквях. В сельских попечительствах иногда практиковалась выдача ссуд зерном с обязательством возвращения. Другие попечительства обеспечивали школьные нужды, заботились об украшении или построении церквей и школ, об открытии и содержании школ, о построении и ремонте причтовых домов. Иногда попечительство ставило перед собой еще какие-нибудь задачи, если считало это необходимым. Например, попечительство в селе Елбанском решило оказывать помощь больным. Членами попечительства была заведена аптечка, которой заведовал священник, выдавая лекарства заболевшим сельчанам [19. С. 22-25].

В некоторых селах местный клир, вслед за городскими приходами, организовывал для прихожан духовно-нравственные чтения. В 1901 г. они были посвящены Святой земле. Здесь многое зависело от инициативности сельского священника. В Гурьевской церкви настоятель о. Павел Любимов добился от местной администрации разрешения проводить чте- 
ния в свободной и просторной «рабочей комнате» при заводе и просил епархиальное начальство разрешить ему употребить из церковных сумм от 70 до 1000 рублей на покупку «волшебного фонаря» и картин для чтений, чтобы сделать их более интересными и людными. В селе Тогурском о. Петр Зайков предварил чтения вступительной беседой о великом значении Святой земли для христиан и об интересе, какой могут дать слушателям чтения об этом. Чтения проводились в селах Колыонском, Березовском, ВерхАнуйском, Федосовском, Бешенцевском, Кабаклинском, Малопесчанском, Елбанском, Вагановском, Шелковниковском, на станции Обь [20. С. 12-18].

Отношение православной церкви к крестьянству имело еще одну важную черту. Среди образованной части русского общества XIX - начала XX в. значительное распространение получила идеология «народничества». Своеобразное «народничество» существовало и в среде консерваторов, в том числе и среди духовенства. В отличие от «разночинского», демократического «народничества», представлявшего народ угнетенным высшими классами, это народничество было реакционным, охранительноклерикальным, видевшим народ, прежде всего крестьян, хранителем патриархальных традиций и носителем духа самодержавия и православия, остающимся «народом-богоносцем», несмотря на попытки его разложения интеллигентами - западниками, либералами и рационалистами. При этом само духовенство, особенно сельское, на собственном опыте знало, чем живет село. Не мог не знать этого и епископат, большая часть которого происходила из семей священников, диаконов и причетников. Тем не менее село продолжали идеализировать.

В 1917 г. после Февральской революции русское общество ожидало выборов в Учредительное собрание, обсуждая будущее государственное устройство России. Не оставалась в стороне от этого всеобщего брожения и православная церковь. В «Епархиальных ведомостях» появилась статья «Второе обращение к Томскому духовенству» епископа Томского и Алтайского Анатолия (Каменского). В духе перемен он благожелательно отозвался о Северо-Американских Соединенных Штатах, однако более предпочтительными для России назвав «государственные порядки и устройство Англии. Англия - страна, в которой вся- кие свободы процветают не менее, чем в республиках, хотя во главе правительства стоит король, возводимый на свой престол чрез помазание и благословение, преподаваемое примасом епископальной англиканской церкви». Говоря же о возможном присутствии церкви в предполагавшемся парламенте он, по прежнему, продолжал искать опору в среде сельского населения: «Хотелось бы видеть создавшуюся и хорошо организованную народно-крестьянскую партию» [21. С. 183-184].

К сожалению, такие реформаторские идеи не получили дальнейшего развития в общественной и политической жизни страны, а Октябрьский переворот привел страну к всеобщему беззаконию и диктатуре, основанной на репрессиях и терроре, которые коснулись и огромной крестьянской массы. Коллективизация сначала ограбила крестьян, лишила их возможности трудиться на себя, а затем и закрепостила, лишив паспортов и возможности менять место жительства и место работы. Началась и активная атеистическая пропаганда среди крестьян, которая была эффективной только для части бывших крестьян, большинство из которых все равно оставались пассивно верующими.

Таким образом, можно сделать вывод, что дореволюционное крестьянство Сибири в целом и Томской губернии в частности оставалось наиболее религиозной частью общества. Однако эта религиозность мало соответствовала учению православной церкви и была переплетена с различными суевериями и народной мифологией. Отношение крестьянства к церкви в целом никогда не было негативным, но политически организоваться оно не умело, а консервативная идеология, проповедуемая с амвонов и газетных страниц, была ему непонятна. Поэтому надежды церковной иерархии и части политически активного духовенства на крестьянство как патриархальную и верную православию народную силу, на которую церковь сможет опереться и утвердить свое влияние в стране, так и не оправдались. Народные массы, преимущественно крестьяне, не смогли пойти за своими пастырями и учителями, которые проповедовали традиционные ценности, а пошли за вождями, которые обещали «манну небесную» под красными флагами и жестоко потом за это поплатились.

\section{ЛИТЕРАТУРА}

1. Памятная книжка Томской губернии на 1912 год. Томск, 1912.

2. Костров Н.А. О расколе в Томской губернии // Томские епархиальные ведомости (далее - ТЕВ). 1883.1 сен.

3. Монастыри в Западной Сибири // ТЕВ. 1881. 15 июня.

4. Доброленский Ф. Религиозно-нравственное состояние Томской епархии с 1834-1884 год // ТЕВ. 1884. 1-15 ноя.

5. Сведения о состоянии церквей, духовенства и прихожан, состоящих в благочинии № 26 за 1891 год // ТЕВ. 1892.15 июля.

6. Новиков И. Томская епархия в 1900 году // ТЕВ. 1901. 1 дек.

7. Обозрение епархии Его преосвященством, преосвященнейшим Макарием, епископом Томским и Барнаульским в летние месяцы 1903 г. // ТЕВ. 1904. 22 марта.

8. Современное расколосектанство в Томской епархии // ТЕВ. 1901. 15 авг.

9. Выдержки из записок миссионера священника Михаила Кондаурова // ТЕВ. 1891. 1 фев. 
10. Записки алтайского миссионера Черно-Ануйского отделения, священника Филарета Синьковского, за 1879 и 1880 годы // ТЕВ. 1882. 1 марта.

11. Отчет об Алтайской духовной миссии за 1880 год // ТЕВ. 1881. 15 авг.

12. Михайловский М. О необходимости и средствах самообразования для духовенства Томской епархии // ТЕВ. 1887. 1 мая.

13. О расколе в Томской губернии : записка, составленная в 1868 году князем Н.А. Костровым // ТЕВ. 1883.15 сен.

14. Костров Н.А. Колдовство и порча между крестьянами Томской губернии. СПб., 1880.

15. Б-нов И. Поучение к сельским прихожанам. О пагубных последствиях пьянства // ТЕВ. 1880. 1 дек.

16. Хорошие меры для отвлечения народа от пьянства // ТЕВ. 1882.1 сен.

17. Пальмов В. Из школьного мира // ТЕВ. 1889. 15 июля.

18. Новиков И. Обозрение епархии Его преосвященством, преосвященнейшим Макарием, епископом Томским и Барнаульским в летние месяцы 1903 г. // ТЕВ. 1904. 1 марта.

19. Новиков И. Томская епархия в 1900 году // ТЕВ. 1901. 15 ноя.

20. Курочкин А. Отчет о деятельности Томского отдела императорского православного Палестинского общества за $1900-1901$ год // TЕВ. 1901. 15 окт

21. Анатолий (Каменский), епископ. Второе обращение к духовенству Томской епархии // ТЕВ. 1917. 15 апр.

\section{Smokotin Stanislaw V. Tomsk State University of Architecture and Building (Tomsk, Russia). E-mail: smokwa@sibmail.com THE ORTHODOX CHURCH AND THE PEASANTRY IN THE TOMSK PROVINCE IN THE XIXth - EARLY XXth CENTURY.}

Keywords: peasantry; Orthodoxy; church; split; Superstition.

In the article the problem of the relationship between the Russian Orthodox Church and the peasantry in the Tomsk province in the $19^{\text {th }}$ - early $20^{\text {th }}$ centuries is considered. A notion is given of the religious mentality of the rural population, the activity of the parish life, the relationship between the Church hierarchy and the peasantry. Orthodox periodicals, statistical publications, works of the famous historian and ethnographer Prince N. Kostrov are the research sources. In the $19^{\text {th }}-$ early $20^{\text {th }}$ centuries peasants made up the largest part of the population of the Russian empire. In 1885 peasants made up 78,16\%, and in $1912-84,77 \%$ of the population of the Tomsk province. The population of Siberia, staying far from the center of the country, and due to slack control on the part of State and Church authorities, had been comparatively indifferent to the Orthodox Church. At the same time, rural population preserved its tradition and culture in the $19^{\text {th }}$ - early $20^{\text {th }}$ centuries. However its faith differed from the official Christian doctrine, and was mingled with superstition and magic. The local population did not know the Church doctrine well enough, and used self-made prayers and apocryphal stories. Part of the rural population openly or covertly supported the Old believers. However the influence of the Old believers depended on their number in the area. Crudeness and ignorance were gradually surpassed by the instillation of civilization and culture among the population. Orthodox Church took part in educational and charitable activity establishing parish schools, charity institutions, delivering lectures. Conservative populism, which existed among the Russian clergy, as well as the conservatives in the Russian empire, was an important feature characterizing the attitude of the Church towards the rural population. The following conclusions were drawn: 1) Church regarded peasantry as the bearer of the Czarist and Orthodox traditions, despite the corrupting propaganda of the liberal intelligentsia; 2) However peasantry lacked comprehension of the conservative ideology. Therefore the hopes of the Church hierarchy and the part of politically active clergy that regarded peasantry as a force patriarchal and true to the Church did not come true.

\section{REFERENCES}

1. Tomsk Province Statistics Committee. (1912) Pamyatnaya knizhka Tomskoy gubernii na 1912 god [Memorandum book of Tomsk province for 1912]. Tomsk: Tipografiya Gubernskogo upravleniya.

2. Kostrov, N.A. (1881) O raskole v Tomskoy gubernii [On the split in Tomsk province]. Tomskie eparkhial'nye vedomosti. 1st September.

3. Anon. (1881) Monastyri v Zapadnoy Sibiri [Monasteries in Western Siberia]. Tomskie eparkhial'nye vedomosti. 15th June.

4. Dobrolenskiy, F. (1884) Religiozno-nravstvennoe sostoyanie Tomskoy eparkhii s 1834-1884 god [Religious and moral state of Tomsk Diocese from 1834-1884]. Tomskie eparkhial'nye vedomosti. 1st - 15th November.

5. Anon. (1892) Svedeniya o sostoyanii tserkvey, dukhovenstva i prikhozhan, sostoyashchikh v blagochinii № 26 za 1891 god [Information about the state of churches, clergy and parishioners of Diocise District No. 26 for 1891]. Tomskie eparkhial'nye vedomosti. 15th July.

6. Novikov, I. (1901) Tomskaya eparkhiya v 1900 godu [Tomsk Diocese in 1900]. Tomskie eparkhial'nye vedomosti. 1st December.

7. Anon. (1904) Obozrenie eparkhii Ego preosvyashchenstvom, preosvyashchenneyshim Makariem, episkopom Tomskim i Barnaul'skim v letnie mesyatsy $1903 \mathrm{~g}$. [Inspection of the diocese by His Eminence, Most Reverend Makarii, Bishop of Tomsk and Barnaul in the summer of 1903]. Tomskie eparkhial'nye vedomosti. 22nd March.

8. Anon. (1901) Sovremennoe raskolosektanstvo v Tomskoy eparkhii [Contemporary schismatics in Tomsk Diocese]. Tomskie eparkhial'nye vedomosti. 15th August.

9. Anon. (1891) Vyderzhki iz zapisok missionera svyashchennika Mikhaila Kondaurova [Excerpts from the notes of missionary priest Michael Kondaurov]. Tomskie eparkhial'nye vedomosti. 1st February.

10. Anon. (1882) Zapiski altayskogo missionera Cherno-Anuyskogo otdeleniya, svyashchennika Filareta Sin'kovskogo, za 1879 i 1880 gody [Notes of the Altai missionary of the Cherno-Anuisk branch, Priest Filaret Sinkovsky, for 1879 and 1880]. Tomskie eparkhial'nye vedomosti. 1st March.

11. Anon. (1881) Otchet ob Altayskoy dukhovnoy missii za 1880 god [Report on the Altai spiritual mission for 1880]. Tomskie eparkhial'nye vedomosti. 15th August.

12. Mikhaylovskiy, M. (1887) O neobkhodimosti i sredstvakh samoobrazovaniya dlya dukhovenstva Tomskoy eparkhii [On the need and means of self-education for the clergy of Tomsk diocese]. Tomskie eparkhial'nye vedomosti. 1st May.

13. Kostrov, N.A. (1883) O raskole v Tomskoy gubernii. Zapiska, sostavlennaya v 1868 godu knyazem N.A. Kostrovym) [On the split in Tomsk province. (Note written in 1868 by Prince N.A. Kostrov)]. Tomskie eparkhial'nye vedomosti. 15th September.

14. Kostrov, N.A. (1880) Koldovstvo i porcha mezhdu krest'yanami Tomskoy gubernii [Witchcraft among peasants of Tomsk province]. St. Petersburg: [s.n.]

15. B-nov, I. (1880) Pouchenie k sel'skim prikhozhanam. O pagubnykh posledstviyakh p'yanstva [Instruction to rural parishioners. On the harmful consequences of drunkenness]. Tomskie eparkhial'nye vedomosti. 1st December. 
16. Anon. (1882) Khoroshie mery dlya otvlecheniya naroda ot p'yanstva [Good measures to distract people from drunkenness]. Tomskie eparkhial'nye vedomosti. 1st September.

17. Palmov, V. (1889) Iz shkol'nogo mira [From the school world]. Tomskie eparkhial'nye vedomosti. 15th July.

18. Novikov, I. (1904) Obozrenie eparkhii Ego preosvyashchenstvom, preosvyashchenneyshim Makariem, episkopom Tomskim i Barnaul'skim v letnie mesyatsy $1903 \mathrm{~g}$. [Ispection of the diocese by His Eminence, Most Reverend Makarii, Bishop of Tomsk and Barnaul in the summer 1903]. Tomskie eparkhial'nye vedomosti. 1st March.

19. Novikov, I. (1901) Tomskaya eparkhiya v 1900 godu [Tomsk Diocese in 1900]. Tomskie eparkhial'nye vedomosti. 15th November.

20. Kurochkin, A. (1901) Otchet o deyatel'nosti Tomskogo otdela imperatorskogo pravoslavnogo Palestinskogo obshchestva za 1900-1901 god [Report on the activities of the Tomsk Division of the Imperial Orthodox Palestine Society for 1900-1901]. Tomskie eparkhial'nye vedomosti. 15th October.

21. Bishop Anatoliy (Kamenskiy). (1917) Vtoroe obrashchenie k dukhovenstvu Tomskoy eparkhii [The second appeal to the clergy of Tomsk Diocese]. Tomskie eparkhial'nye vedomosti. 15th April. 